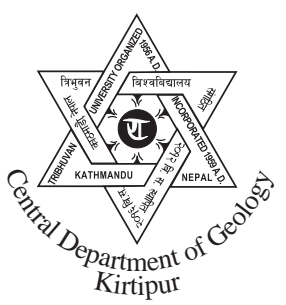

\title{
Engineering hydrology of Kodku Khola Basin, Lalitpur, Nepal
}

\author{
${ }^{*}$ Laxmi Devi Maharjan ${ }^{1}$ and Vishnu Dangol ${ }^{2}$ \\ ${ }^{1}$ Central Department of Geology, Tribhuvan University, Kathmandu, Nepal \\ ${ }^{2}$ Department of Geology, Tri-Chandra Multiple Campus, Tribhuvan University, Kathmandu, Nepal
}

\begin{abstract}
Not only in rural areas but also in urban areas, vast number of people lack access to safe drinking water. The city of Lalitpur is in severe deficit of drinking water for its population. Hydrological study of the Kodkhu Khola Basin near the Lalitpur City was carried out in pre-feasibility level. Rainfall data were analysed to estimate future rainfall trend that would determine the rainfall intensity, frequency, maximum and minimum rainfalls. The discharge of the river was estimated by float method. About $70 \%$ of flow in the river occurred in monsoon from June to September. The mean yearly rainfall of ten years of record was $1238 \mathrm{~mm}$ in the Khumaltar Station and $1494 \mathrm{~mm}$ in the Godawari Station. The intensity of the maximum rainfall in a day of each of ten years fell in the heavy category and most of the years fell in the normal year category. Maximum rainfall of 100 year's recurrence interval will have magnitude of $1595 \mathrm{~mm}$. The discharge ranged from $17.35 \mathrm{~m}^{3} / \mathrm{s}$ to $56.94 \mathrm{~m}^{3} / \mathrm{s}$ in the upstream reaches. The amount of rainfall and discharge is thought to be sufficient for maintaining the reservoir for drinking water supply in Lalitpur city and the Kodku Khola is appreciable for the drinking water source.
\end{abstract}

\section{INTRODUCTION}

The Lalitpur submetropolitan city suffers drinking water deficit as only 112 million liters per day have been supplied against the demand of about 177 million liters per day in the Kathmandu Valley by Nepal Drinking Water Corporation (NDWSC 2001). Several headwaters of the tributaries of the Bagmati River have been utilised as the sources of drinking water. The Kodku Khola as the nearest river from the Lalitpur city may become useful resource for the water supply purpose, if the detail hydrological and engineering geological study is made. Therefore, to identify the Kodku Khola as one of the resources, we carried out pre-feasibility study of hydrology of the river basin to estimate discharge of the river, and future rainfall trend that would determine the rainfall intensity, frequency, maximum and minimum rainfalls. From the study we have suggested an appropriate site for the reservoir and dam.

\footnotetext{
*Corresponding author:

E-mail address: sulaxam@yahoo.com
}

\section{GEOLOGY OF STUDY AREA}

The Kodku Khola watershed is located in the southern part of the Kathmandu basin (Fig. 1) covering about $34 \mathrm{sq}$. km. The river is the north flowing tributary of the Manahara River, which drains into the Bagmati River. The river course originates from the mountainous area (Elv. $1970 \mathrm{~m}$ amsl.) and flows towards valley plain (Elv. $1360 \mathrm{~m}$ amsl.). The Kodku Khola has a total length of $23.2 \mathrm{~km}$ and its watershed is $10 \mathrm{~km}$ long along the north-south direction and nearly $5 \mathrm{~km}$ wide in east west direction.

The Kodku Khola has a dendritic drainage pattern which originates from the catchments of the Chandragiri Limestone of Paleozoic epoch (Stocklin and Bhattarai 1977). The limestones are blue grey, fine-grained and are siliceous to dolomitic. The PlioPleistocene sediments of the study area mainly comprise the Lukundol Formation and the Chapagaon Formation (Fig. 2) (Yoshida and Igarashi 1984; DMG 1998). The Lukundol Formation consists of weakly consolidated black to dark grey clay, silt and fine sand. The Chapagaon Formation consists of gravel 


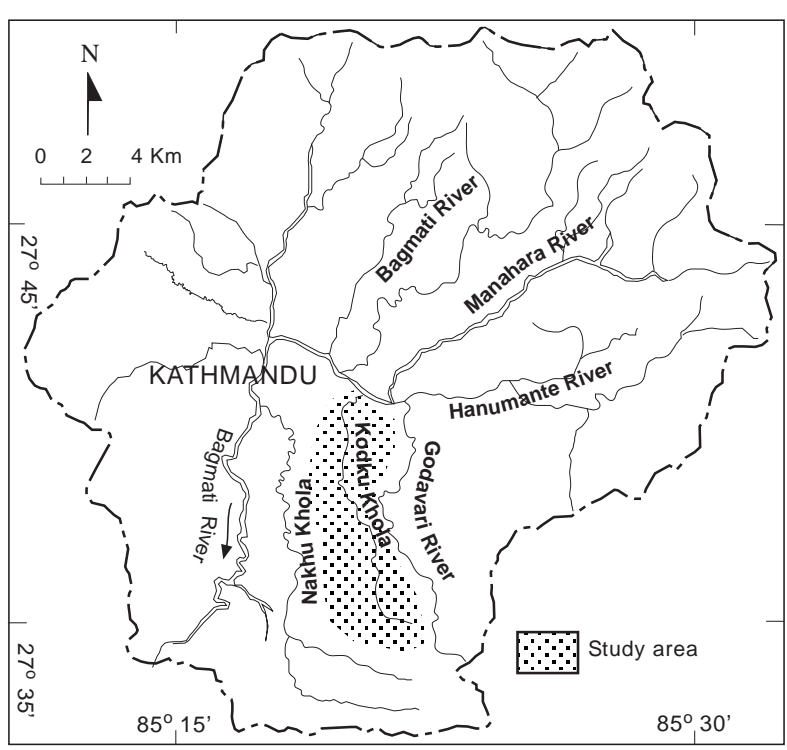

Fig. 1 Location map of study area

and sand with varying proportion of silt. The formation is exposed at the upper part of the slopes on the river banks forming steep scarp slopes.

Along the valley of the Kodku Khola ,the recent terrace and flood plain deposits are distributed. These terrace deposits extend east of Badikhel. Wide flood plain deposist occupies the area east of Khumaltar and north of Dhapakhel. In the lower reaches of the river, the flood plains that overlie the Lukundol Formation have been extensively developed. The flood plain deposits in the upper reaches consist of grey clayey silt to light brown silty sand, pebble and cobble. Pebbles and cobbles are composed of limestone, metasandstone, marble and phyllite. In the lower reaches of the river, the flood plain deposit comprises fine- to coarse-grained sand and gravel.

The landuse in the Kodku Khola watershed is cultivated with paddy rice, wheat and vegetables extending from terrace up the gentle slope of the upstream mountain.

\section{HYDROLOGY}

\section{Rainfall}

Rainfall in the Kathmandu Valley occurs mainly between middle of June and middle of September. About 80 percent of the annual rainfall occurs in this period (monsoon period). The other rainfall period is the pre-monsoon period from March to May .
The rainfall data of the year 1994-2004 were obtained from the rain gauge stations (Khumaltar 1029 and Godawari 102294) from DHM (2003).

From the rainfall data seasonal and annual rainfall variation and rainfall distribution at various frequency was analysed. Nextly, the rainfall intensity, duration, frequency, maximum and minimum rainfall were determined. The mean monthly rainfall distribution at the Khumaltar Station has been shown in Fig. 3a, and the Godawari Station has been shown in Fig. 3b. From the mean monthly rainfall, normal, abnormal and drought months of the year were predicted.

The mean yearly rainfall during 1994-2004 was $1238 \mathrm{~mm}$ in the Khumaltar Station and $1494 \mathrm{~mm}$ in the Godawari Station. The mean annual rainfall was used to find out normal, abnormal and drought rainfall defined interms of the amount of rainfall at a particular year received. Normal year is the one that receives the rainfall between the upper and the lower limits of the mean rainfall plus one standard deviation (Table 1). Abnormal year or wet year receives the rainfall exceeding or equal to the upper limit (mean rainfall plus one standard deviation). Drought year generally receives rainfall less than or equal to the lower limit (mean minus one standard deviation). For the Kodku Khola basin the normal year, abnormal year and drought year rainfall limiting values are respectively 1079-1397, 1397 and 1079.

\section{Rainfall intensity}

The Khumaltar Station is a non-recording type of rain-gauge station. Intensity (I) of the rainfall was obtained from the ratio $d / t$, where $d$ was depth fo precipitation and $t$ was duration of precipitation. Based on the numerical value of intensity, the following three types of rainfall are suggested: light (upto $2.6 \mathrm{~mm} / \mathrm{hr}$ ), moderate $(2.6$ to $7.6 \mathrm{~mm} / \mathrm{hr}$ ) and heavy $(>7.6 \mathrm{~mm} / \mathrm{hr})$. The maximum rainfall intensity in a day for each year was computed by dividing the maximum rainfall depth on a particular day by 24 hours. From the Table 2, the intensity of the maximum rainfall in a day of each of ten years falls in the heavy category. The rainfall data of the Godawari Station indicate that the rainfall internsity is heavy and most of the year fall in normal year.

\section{Rainfall frequency}

Design of hydraulic structures such as flood control structures, soil conservation structures, sewage system, 


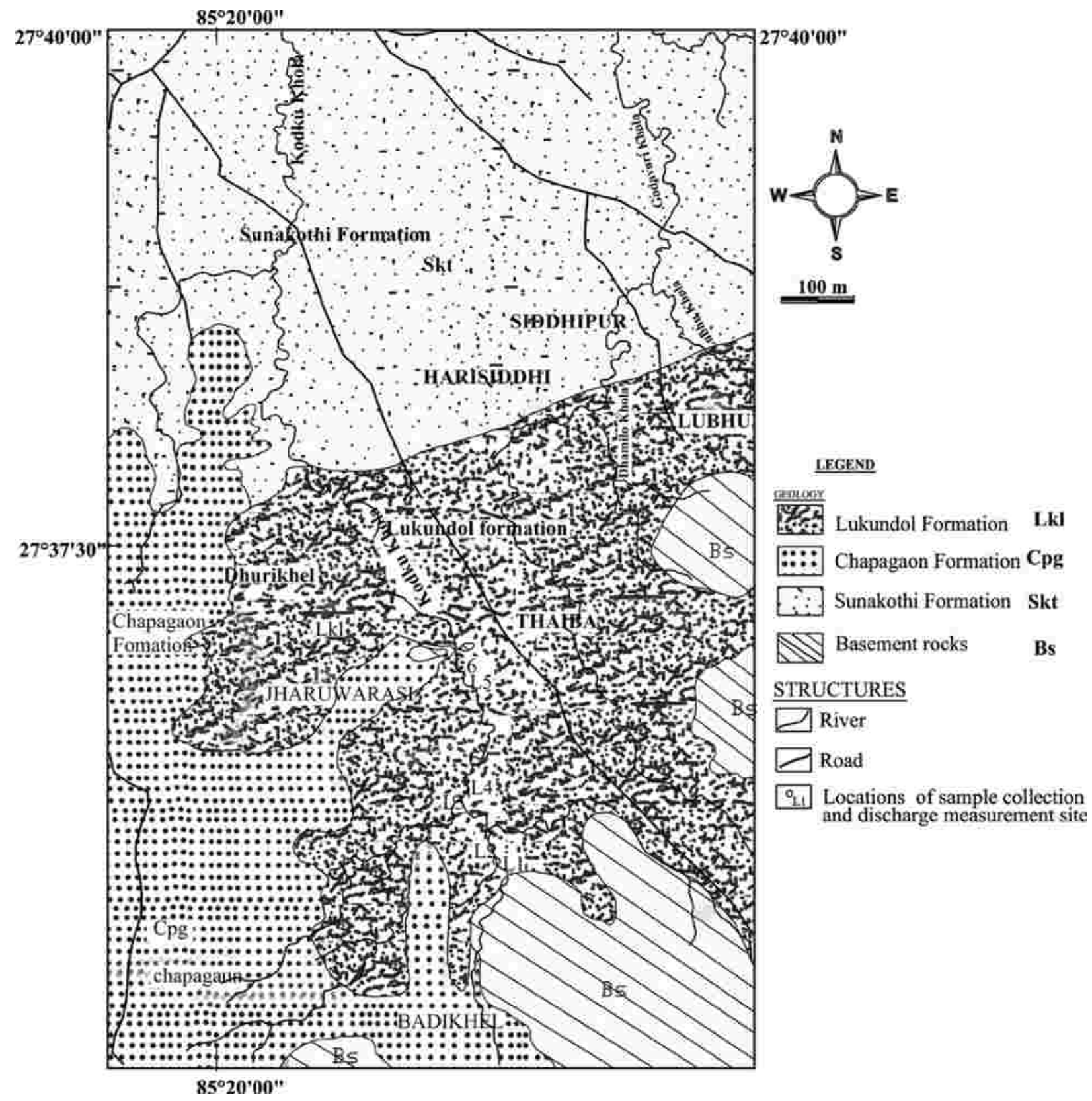

Fig. 2 Geological map of the Kodku Khola area 
(a)

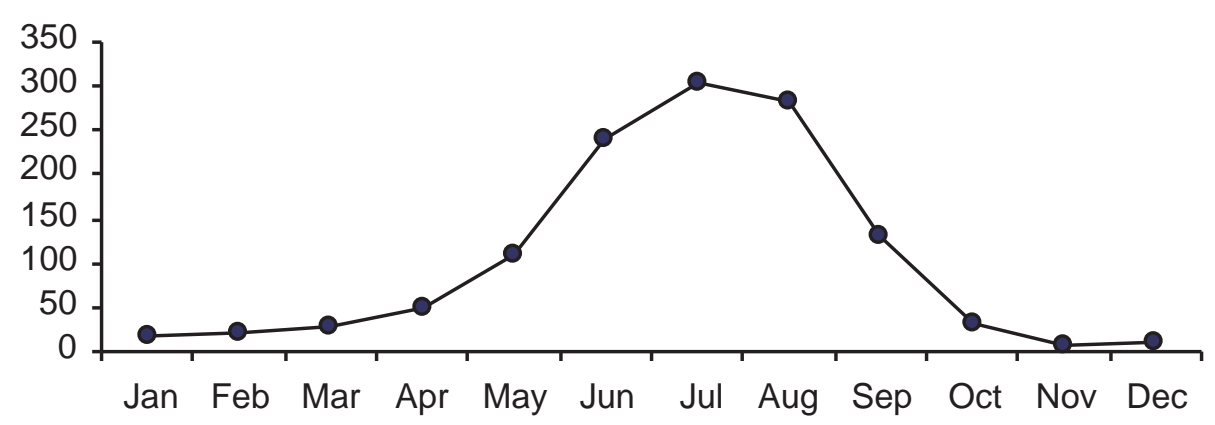

(b)

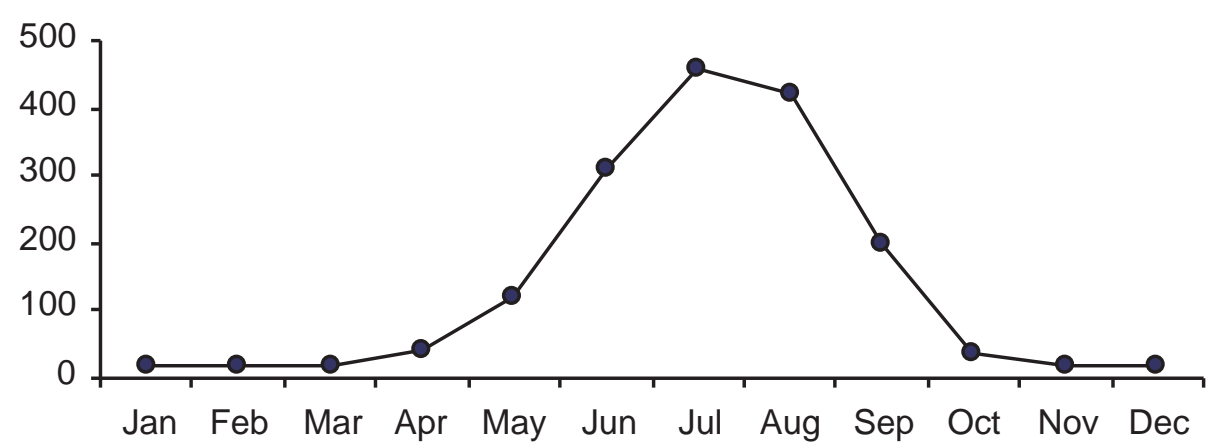

Fig. 3 Average monthly rainfall distrubution (a) Khumaltar Station: records between 1994 and 2003 (b) Godavari Station: records between 1994 and 2002; (after DHM (2003)

drains and culverts is based on the probability of the occurrence of extreme rainfall and runoff. Frequency of rainfall of a specified period is expressed in terms of recurrence interval which is defined as the value that is equal to or greater than the specified magnitude occurred once in a year. The recurrence interval $(\mathrm{T})$ is the ratio of $1 / \mathrm{P}$, where $\mathrm{P}$ is the probability of the event. There are various methods available for computing the recurrence interval, for example, Weibul's method, California method and Hazen's method as defined below:

$$
\begin{array}{ll}
\mathrm{T}=(\mathrm{N}+1) / \mathrm{M} & (\text { Weibul }) \\
\mathrm{T}=\mathrm{N} / \mathrm{M} & \text { (California) } \\
\mathrm{T}=2 \mathrm{~N} /(2 \mathrm{M}-1) & \text { (Hazen) }
\end{array}
$$

where, $\mathrm{T}$ is return period (years), $\mathrm{n}$ is the total number of events and $\mathrm{m}$ is the rank number assigned to the event, when rainfall data are arranged in descending order by their magnitutde, i. e., the highest magnitude is ranked as 1 and so on.

The rainfall data were arranged in descending order. Rank number was assigned to each event. Recurrence interval of each event was determined using the Hazen's equation (3). The position of each event was found from the relation:

$$
\mathrm{P}=(1 / \mathrm{T}) 100
$$

The rainfall data were plotted against respective probability on the semi-log paper, which yielded a straight line. For reliability and validity of this plot, rainfall data of at least twenty-five years will be required. However, the smaller number of data may also be usefull, but there will be low accuracy in prediction using such a small number of data.

The details about the calculation of reccurence 
Table 1: Calculation of mean and standard deviation of the annual rainfall data of the Khumaltar Station recorded between year 1994 and 2004

\begin{tabular}{|c|c|c|c|}
\hline Year & Annual rainfall, $\mathrm{X}_{\mathrm{i}}(\mathrm{mm})$ & $\mathrm{X}_{\mathrm{i}}$ MEAN & $\left(\begin{array}{ll}\mathrm{X}_{\mathrm{i}} & \mathrm{MEAN}\end{array}\right)^{2}$ \\
\hline 1994 & 1227.4 & -1.0 & 1 \\
\hline 1995 & 1296.2 & 5.8 & 34 \\
\hline 1996 & 1126.3 & -11.2 & 124 \\
\hline 1997 & 1134.7 & -10.3 & 106 \\
\hline 1998 & 1155.3 & -8.3 & 68 \\
\hline 1999 & 1275.1 & 3.7 & 14 \\
\hline 2000 & 1196.0 & -4.2 & 17 \\
\hline 2001 & 991.2 & -24.7 & 608 \\
\hline 2002 & 1535.3 & 29.8 & 885 \\
\hline 2003 & 1440.4 & 20.3 & 410 \\
\hline \multirow[t]{2}{*}{ Total } & 12377.9 & -0.01 & 2269 \\
\hline & MEAN $=123.78$ & STDEV = & 15.88 \\
\hline
\end{tabular}

Table 2: Maximum rainfall intensity

\begin{tabular}{llccc}
\hline Year & $\begin{array}{c}\text { Year } \\
\text { type }\end{array}$ & $\begin{array}{c}\text { Maximum rain fall } \\
\text { of a day }(\mathrm{mm})\end{array}$ & $\begin{array}{c}\text { Rainfall } \\
\text { intensity }(\mathrm{mm} / \mathrm{hr})\end{array}$ & $\begin{array}{c}\text { Type of } \\
\text { intensity }\end{array}$ \\
\hline 1994 & NY & 301.6 & 12.6 & Heavy \\
1995 & NY & 456.3 & 19.0 & Heavy \\
1996 & NY & 343.5 & 14.3 & Heavy \\
1997 & NY & 305.7 & 12.7 & Heavy \\
1998 & NY & 302.0 & 12.6 & Heavy \\
1999 & NY & 421.2 & 17.6 & Heavy \\
2000 & NY & 309.3 & 12.9 & Heavy \\
2001 & DY & 247.5 & 10.3 & Heavy \\
2002 & NY & 436.2 & 18.2 & Heavy \\
2003 & NY & 398.6 & 16.6 & Heavy \\
\hline
\end{tabular}

$\mathrm{NY}=$ Normal year; DY $=$ Dry year

interval (T) and probability of occurrence of such event $(\mathrm{P})$ are shown in Table 3. The rainfall frequency curves were obtained in the form of recurrence interval and the form of percent probability. The former was obtained by plotting the annual rainfall amount on ordinate and recurrence interval on abscissa using semi-log paper (Figs. 4 and 5).

\section{Maximum and minimum rainfalls}

The maximum and minimum rainfalls in the Khumaltar Station were calculated for specified recurrence intervals. The results are shown in Table 4. Maximum rainfall of 100 year's recurrence interval will have magnitude of $1595 \mathrm{~mm}$.

\section{Discharge}

Discharge (Q) was calculated from the product of average stream velocity $(\mathrm{V})$ and cross-sectional area (A) perpendicular to flow. Actual velocity varies along the river length, width and depth. The float method was used to measure surface velocity.

Major tributaries of the watershed are fed by perennial resources with seasonal fluctuation of discharge amount, which is enhanced by many seasonal tributaries. There are some springs and ponds sourced to groundwater, which add to the discharge of the watershed. The discharge was obtained from six different location points in the river (Fig. 2) during 
the year 2003. The discharge ranged from $17.35 \mathrm{~m}^{3} / \mathrm{s}$ in location L2 to $56.94 \mathrm{~m}^{3} / \mathrm{s}$ in location L3 in the upstream reaches, and gradually decreased from L3 to L5 towards downstream reach (Table 5).

\section{RESERVOIR SITE}

Topography at the reservoir site is steep with slope varying from 25 to 50 degrees (Fig. 6). However, a major part of the Kodku Khola vallies exhibits landforms carved out into terraces. Such terraces lie at the elevation of $1500 \mathrm{~m}$ amsl. The valleys in this elevation are wide with wider flood plain, low bank

Table 3: Recurrence interval and probability of rainfall

\begin{tabular}{ccccc}
\hline Year & $\begin{array}{c}\text { Rank } \\
\text { M }\end{array}$ & $\begin{array}{c}\text { Annual } \\
\text { rainfall }(\mathrm{mm})\end{array}$ & $\begin{array}{c}\text { Recurrence } \\
\text { interval, T (yrs) }\end{array}$ & $\begin{array}{c}\text { Probability, } \\
\text { P }(\%)\end{array}$ \\
\hline 1994 & 1 & 1227.4 & 20.0 & 5 \\
1995 & 2 & 1296.2 & 6.7 & 15 \\
1996 & 3 & 1126.3 & 4.0 & 25 \\
1997 & 4 & 1134.7 & 2.9 & 35 \\
1998 & 5 & 1155.3 & 2.2 & 45 \\
1999 & 6 & 1275.1 & 1.8 & 55 \\
2000 & 7 & 1196.0 & 1.5 & 65 \\
2001 & 8 & 991.2 & 1.3 & 75 \\
2002 & 9 & 1535.3 & 1.2 & 85 \\
2003 & 10 & 1440.4 & 1.1 & 95 \\
\hline
\end{tabular}

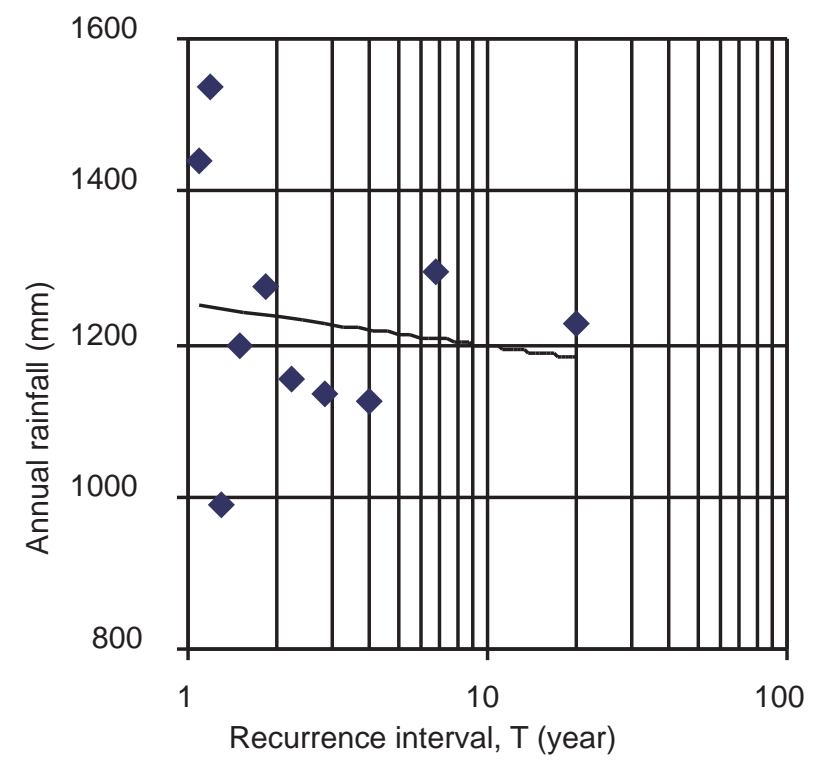

Fig. 4 Recurrence interval of different magnitudes of rainfall using Hazen's method
Table 4: Maximum and minimum rainfalls and recurrence intervals

\begin{tabular}{ccc}
\hline $\begin{array}{c}\text { Recurrence } \\
\text { interval (yrs) }\end{array}$ & $\begin{array}{c}\text { Maximum } \\
\text { rainfall (mm) }\end{array}$ & $\begin{array}{c}\text { Minimum } \\
\text { rainfall (mm) }\end{array}$ \\
\hline 10 & 1360 & 11200 \\
20 & 1450 & 1220 \\
30 & 1480 & 1170 \\
40 & 1500 & 1150 \\
50 & 1520 & 1140 \\
60 & 1540 & - \\
70 & 1560 & - \\
80 & 1585 & - \\
90 & 1590 & - \\
100 & 1595 & - \\
\hline
\end{tabular}

Table 5: Stream discharge using float method

\begin{tabular}{cc}
\hline Location & Discharge $\left(\mathrm{m}^{3} / \mathrm{s}\right)$ \\
\hline L1 & 22.24 \\
L2 & 17.35 \\
L3 & 56.94 \\
L4 & 47.24 \\
L5 & 38.99 \\
L6 & 49.57 \\
\hline
\end{tabular}

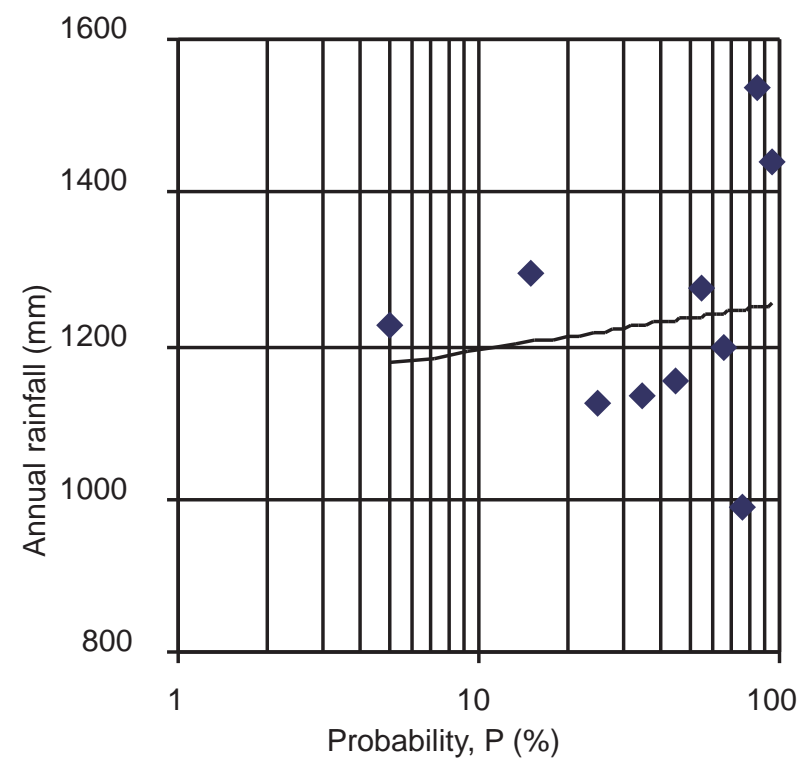

Fig. 5 Probability of recurrence of rainfall using Hazen's method 


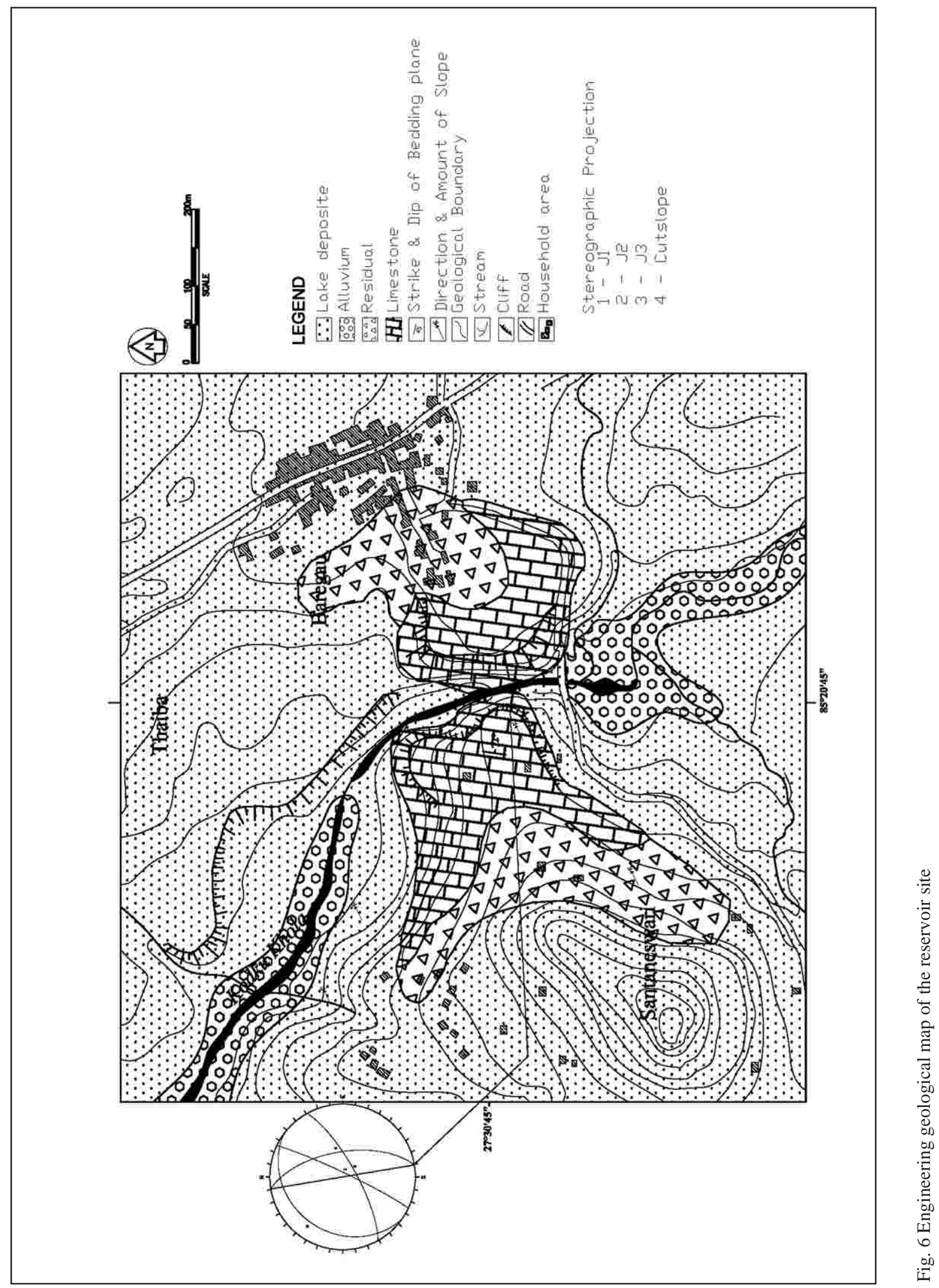




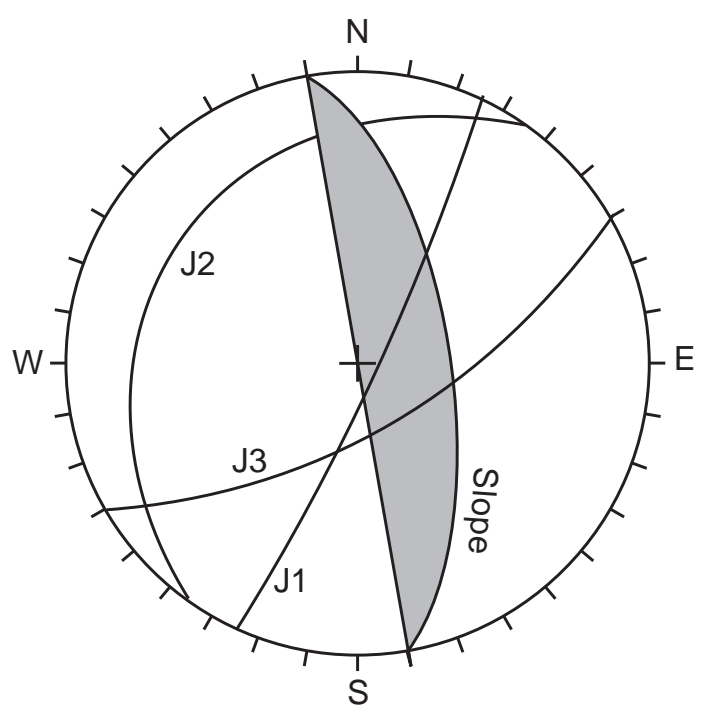

Fig. 7 Stereographic projection of joints

heights and meandering.

The reservoir site locates in the river reach underlain by limestones of the Chandragiri Limestone (Fig. 6). The bedrock crops out for about $250 \mathrm{~m}$ in the site and forms a narrow gorge. Beds have orientation $\left(\mathrm{N} 80^{\circ} \mathrm{W} / 80^{\circ} \mathrm{NE}\right)$ oblique to the river flow direction (NE). Bedrocks are composed of massive, yellow to brown and weathered limestone with argillaceous partings of less than 0.1 to $0.5 \mathrm{~m}$. Beds have thickness ranging from $0.1 \mathrm{~m}$ to $0.7 \mathrm{~m}$. At the dam site, bedrocks are exposed at both the banks of the Kodku Khola. At the top of the ridge and slopes of the ridge, rocks are weathered giving rise to 1 to $4 \mathrm{~m}$ thick residual soil.

In the bedrocks of the dam site, three prominent joint sets were measured (Fig. 7); J1 $\left(115^{\circ} / 50^{\circ}\right)$, J2 $\left(306^{\circ} / 26^{\circ}\right)$ and $\mathrm{J} 3\left(151^{\circ} / 73^{\circ}\right)$. The attitude of cut slope $\left(81 \% 63^{\circ}\right)$ showed that the wedges formed by intersecting two of joint sets $\mathrm{J} 1$ and $\mathrm{J} 3$, and $\mathrm{J} 2$ and $\mathrm{J} 3$ oriented in the opposite directions of the cut slope. This means probability of failure due to the wedges formed by intersecting joints is very low.

Possible location of the reservoir and dam site is limited considering topography of the Kodku Khola basin. The most favourable location is a narrow gorge of the river near Boregaon village (Fig. 8). The river is located near to the main city and the required length of supply system is minimum.

The rock slope around the area is almost stable. The colluvium at the north-facing slope has been found very thick.

\section{WATER QUALITY OF RIVER}

Surface water drawn from the Kodku Khola was physically and chemically analysed. The results are indicated in Table 6 . Turbidity was found to be less

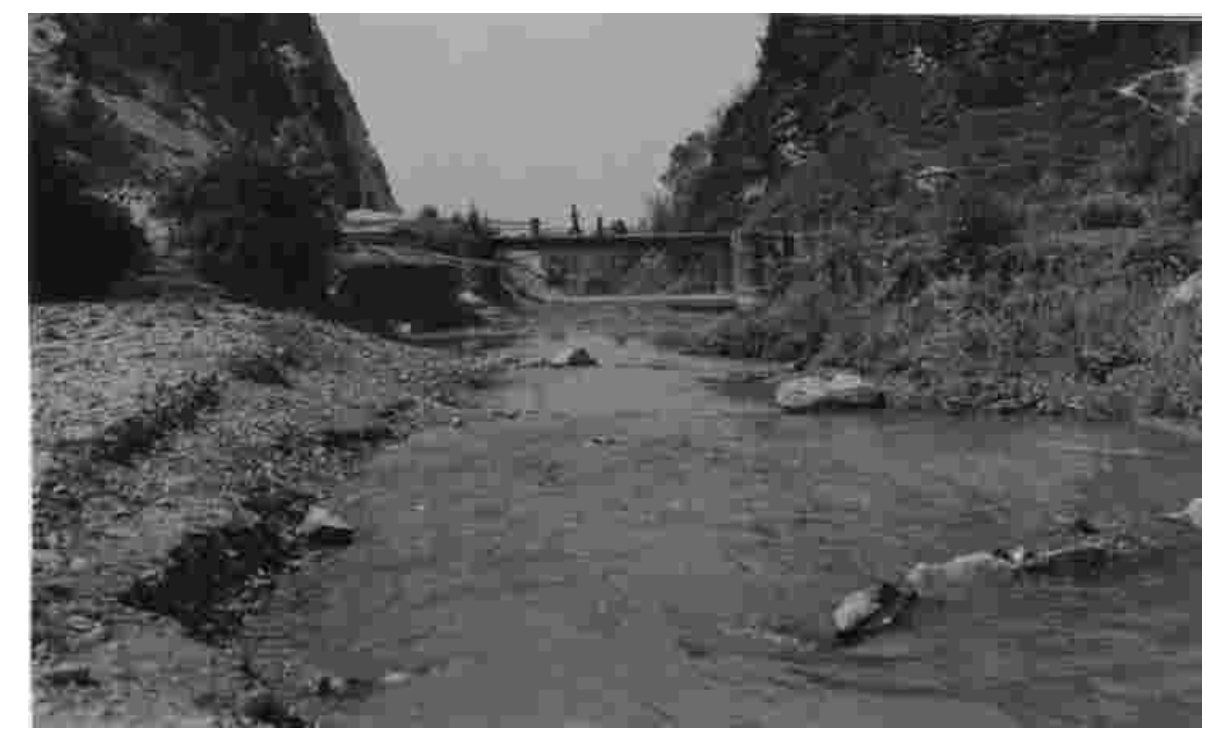

Fig. 8 Photograph showing suggested dam and reservoir site in the Kodku Khola 
Table 6: Chemical analysis of surface water from the Kodku Khola at sample site L4 (The values are expressed as mg/l, unless otherwise specified and except $\mathrm{pH}$ )

\begin{tabular}{|c|c|c|c|c|}
\hline S.N. & Parameters & Unit & Result & Normal level \\
\hline 1 & Appearance & & Clear & \\
\hline 2 & Turbidity & NTU & $<5$ & $(5-25)$ \\
\hline 3 & Colour & Hazen & $<5$ & $5-50)$ \\
\hline 4 & Temperature & ${ }^{\mathrm{o}} \mathrm{C}$ & $17^{\circ} \mathrm{C}$ & \\
\hline 5 & $\mathrm{pH}$ & & 7.68 & $(6.5-9.2)$ \\
\hline 6 & Electrical Conductivity & $\mathrm{S} / \mathrm{cm}$ & 163.0 & $(400-1250)$ \\
\hline 7 & Total Alkalinity & as $\mathrm{CaCO}_{3}$ & 106.0 & \\
\hline 8 & pH Alkalinity & as $\mathrm{CaCO}_{3}$ & Nil & \\
\hline 9 & pH 4.5 Alkalinity & as $\mathrm{CaCO}_{3}$ & 148.0 & \\
\hline 10 & Total Hardness & as $\mathrm{CaCO}_{3}$ & 110.0 & $(100-500)$ \\
\hline 11 & Calcium Hardness & as $\mathrm{CaCO}_{3}$ & 68.0 & \\
\hline 12 & Magnesium Hardness & as $\mathrm{CaCO}_{3}$ & 42.0 & \\
\hline 13 & Calcium & as $\mathrm{Ca}$ & 28.12 & $(75-200)$ \\
\hline 14 & Magnesium & as $\mathrm{mg}$. & 12.25 & $(<30-150)$ \\
\hline 15 & Total Iron & as $\mathrm{Fe}$. & 0.5 & $(0.1-1)$ \\
\hline 16 & Manganese & as Mn. & & $(0.05-0.5)$ \\
\hline 17 & Silica & as $\mathrm{SiO}_{2}$ & & \\
\hline 18 & Total Ammonia & as $\mathrm{N}$. & 0.03 & $(0.05-1.5)$ \\
\hline 19 & Nitrite & as $\mathrm{N}$ & & \\
\hline 20 & Nitrate & as $\mathrm{N}$ & & (upto 10) \\
\hline 21 & Orthophosphate & as $\mathrm{P}$. & & \\
\hline 22 & Chloride & as $\mathrm{Cl}$. & 10.0 & (up to 250 ) \\
\hline
\end{tabular}

than 20 NTU, but it would be expected to reach 200 NTU during the monsoon season. Therefore treatment would be necessary. Total hardness in terms of calcium carbonate ranged between 100 and $124 \mathrm{mg} / \mathrm{l}$. This could be classified as hard water. The water contained sodium bicarbonate alkalinity. Chloride content of the water was $0.1 \mathrm{mg} / \mathrm{l}$ which was rather small. It would become more during monsoon season.

\section{CONCLUSIONS}

About $70 \%$ of flow in the Kathmandu Valley occurs in monsoon months, which is from June through September. The mean yearly rainfall of ten years' record is $1238 \mathrm{~mm}$ in the Khumaltar Station and $1494 \mathrm{~mm}$ in the Godawari Station. For the Kodku Khola basin the normal year, abnormal year and drought year rainfall limiting values are respectively 1079-1397, 1397 and 1079. The intensity of the maximum rainfall in a day of each of ten years falls in the heavy category and most of the years fall in normal year. Similarly, the rainfall data of the Godawari Station indicate that the rainfall intensity is heavy and most of the year fall in normal year. Maximum rainfall of 100 year's recurrence interval will have magnitude of $1595 \mathrm{~mm}$. The discharge ranged from $17.35 \mathrm{~m}^{3} / \mathrm{s}$ to $56.94 \mathrm{~m}^{3} / \mathrm{s}$ in the upstream reaches. The amount of rainfall and discharge is thought to be sufficient for maintaining the reservoir for drinking water supply in Lalitpur city. Therefore, the Kodku Khola is appreciable for the drinking water source if implemented.

\section{ACKNOWLEDGEMENT}

Authors are thankful to Central Department of Geology, Tribhuvan University, Kirtipur. Authors thank A. M. Pradhan for helping in field. Authors are 
thankfull to C. B. Shrestha for valuable comments.

\section{REFERENCES}

DHM, 2003. Rainfall data of Khumaltar Station recorded during 1994-2004. Electronic data obtained from Department of Hydrology and Meteorology (DHM), Nepal Government, Babar Mahal, Kathmandu, Nepal.

DMG, 1998. Engineering and environmental geological map of the Kathmandu Valley, scale 1:50,000. Department of Mines and Geology (DMG), Lainchaur,
Kathmandu, Nepal.

NDWSC, 2001. Annual report: comparative operative data, Nepal Drinking Water Supply Corporation (NDWSC), 11p.

Stocklin, J. and Bhattarai, K.D., 1977. Geology of Kathmandu area and central Mahabharat Range, Nepal Himalayas. Technical Report (Unpublished), UNDP Mineral exploration project, Kathmandu, 86p. Yoshida, M. and Gautam, P,. 1988. Neogene to Quaternary lacustrine sediments in the Kathmandu Valley, Nepal. Journal of Nepal Geological Society, v. 4, pp. 73-100. 